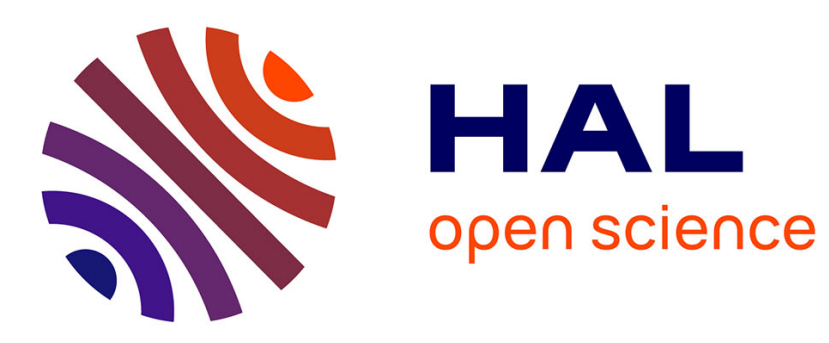

\title{
Collaborative Inquiry Learning: Models, Tools, and Challenges
}

Thorsten Bell, Detlef Urhahne, Sascha Schanze, Rolf Ploetzner

\section{To cite this version:}

Thorsten Bell, Detlef Urhahne, Sascha Schanze, Rolf Ploetzner. Collaborative Inquiry Learning: Models, Tools, and Challenges. International Journal of Science Education, 2010, 32 (03), pp.349-377. 10.1080/09500690802582241. hal-00559600

\section{HAL Id: hal-00559600 https://hal.science/hal-00559600}

Submitted on 26 Jan 2011

HAL is a multi-disciplinary open access archive for the deposit and dissemination of scientific research documents, whether they are published or not. The documents may come from teaching and research institutions in France or abroad, or from public or private research centers.
L'archive ouverte pluridisciplinaire HAL, est destinée au dépôt et à la diffusion de documents scientifiques de niveau recherche, publiés ou non, émanant des établissements d'enseignement et de recherche français ou étrangers, des laboratoires publics ou privés. 


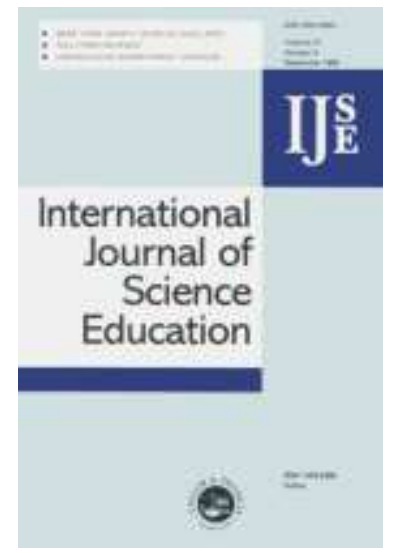

\section{Collaborative Inquiry Learning: Models, Tools, and Challenges}

\begin{tabular}{|r|l|}
\hline Journal: & International Journal of Science Education \\
\hline Manuscript ID: & TSED-2007-0381.R1 \\
\hline Manuscript Type: & Research Paper \\
\hline Keywords: & $\begin{array}{l}\text { science education, inquiry-based teaching, information technology, } \\
\text { learning environment }\end{array}$ \\
\hline Keywords (user): & $\begin{array}{l}\text { collaborative inquiry learning, model of inquiry processes, computer } \\
\text { assistance }\end{array}$ \\
\hline
\end{tabular}

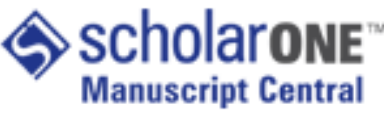




\title{
Collaborative Inquiry Learning: Models, Tools, and Challenges
}

\begin{abstract}
Collaborative inquiry learning is one of the most challenging and exciting ventures for today's schools. It aims at bringing a new and promising culture of teaching and learning into the classroom where students in groups engage in self-regulated learning activities supported by the teacher. It is expected that this way of learning fosters students' motivation and interest in science, that they learn to perform steps of inquiry similar to scientists and that they gain knowledge on scientific processes. Starting from general pedagogical reflections and science standards the article reviews some prominent models of inquiry learning. This comparison results in a set of inquiry processes being the basis for cooperation in the scientific network NetCoIL. Inquiry learning is conceived in several ways with emphasis on different processes. For an illustration of the spectrum, some main conceptions of inquiry and their focuses are described. In the next step, the article describes exemplary computer tools and environments from within and outside the NetCoIL network that were designed to support processes of collaborative inquiry learning. These tools are analysed by describing their functionalities as well as effects on student learning known from the literature. The article closes with challenges for further developments elaborated by the NetCoIL network.
\end{abstract}

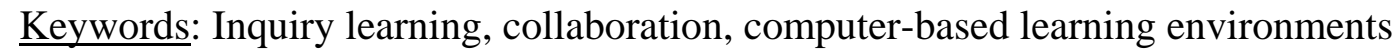




\section{Introduction}

Collaborative inquiry learning is a mixed term whose meaning is derived from the demand of practicing inquiry in science education (National Research Council, 1996) and the increasing proliferation of computer-supported collaborative learning (CSCL) in the past few years (Koschmann, 1996; Koschmann, Hall, \& Miyake, 2001; Strijbos, Kirschner, \& Martens, 2004). As a result of collaborative inquiry learning, students acquire knowledge of how to do science as a common endeavour, they learn about the nature of science and the scientific content. By the development of powerful computer-based learning environments (de Corte, Verschaffel, Entwistle, \& van Merriënboer, 2003) collaborative inquiry learning gained additional options. Learning technology can support students as they work in collaborative inquiry projects by taking over some of the teachers' responsibilities and enabling direct exchange among students, also across wider distances and at different times.

The purpose of this article is twofold. First, we present the theoretical foundations and connotations of the term 'collaborative inquiry learning' to clarify its meaning and importance for science education. Second, we highlight the benefits of computerised tools in enabling and enhancing collaborative inquiry learning processes. We provide, therefore, examples of computer-based learning environments designed by several established work groups, in particular by members of our scientific network NetCoIL. The network consists of scientists from Canada, the U.S., the Netherlands, Norway, Spain and Germany and has been established to compare and integrate different technological approaches.

The importance of collaborative inquiry learning

The call for inquiry learning is based on the conviction that science learning is more than the memorization of scientific facts and information, but rather is about understanding and applying scientific concepts and methods. This special emphasis on methods can be traced back up to the work of Dewey $(1910,1938)$. He argued that scientific knowledge develops as 
a product of inquiry. Therefore, students' attitude to find inquiry-based solutions for authentic problems should be promoted. Dewey's historical notions are in accordance with current approaches of situated learning (Greeno, Collins, \& Resnick, 1996; Henning, 2004). Situated learning aims to prevent what Whitehead (1929) termed 'inert knowledge'. Knowledge is considered as 'inert' when there is a lack of knowledge transfer in problem solving situations that demand the use of already acquired knowledge (Renkl, Mandl, \& Gruber, 1996). By inquiring complex problems knowledge may become less inert and more applicable (Edelson, 2001).

Moreover, national guidelines for science education stress the special value of inquiry learning. The National Science Education Standards of the U.S. put strong emphasis on activities that investigate and analyse science questions (National Research Council, 1996). Like real scientists students should study the natural world, make their own observations and propose explanations based on the evidence of their own work. In Germany, as a political reaction to the mediocre performance of German students in the Programme for International Student Assessment (Centre for Educational Research and Innovation, 2001), national science education standards were introduced in four main competence areas: domain-specific knowledge, methodological knowledge, communication, and judgement (Sekretariat der Ständigen Konferenz der Kultusminister der Länder in der Bundesrepublik Deutschland, 2005). The area 'methodological knowledge' encompasses many inquiry learning related activities and emphasises the importance of this educational dimension.

Inquiry learning often incorporates an element of collaboration meaning the engagement of participants in a common endeavour (Dillenbourg, 1999). There are a number of arguments why collaboration among learners is effective for inquiry-based learning. According to socioconstructivistic learning theories (Duit \& Treagust, 1998) knowledge emerges by collaborative search of problem solutions in communities with distributed information among its members. Piaget (1926) pointed at the importance of social interaction for the emergence 
of cognitive conflicts. These socio-cognitive conflicts form the basis of considerable cognitive developments and performances and might appear in inquiry learning processes as well (Lethinen, 2003). Finally, Vygotsky’s (1978) idea of the 'zone of proximal development' has been helpful for understanding the effects of collaborative experiences; collaborating peers offer zones of proximal development to each other. Crook (1991) further developed the idea to capture the whole of the context formed by classmates, the teacher, and technical media in which learning takes place. In the meantime theoretical reflections and empirical studies have demonstrated the potential of student collaboration, the role computer tools can play to support it as well as conditions for success (e.g. Pilkington, 2004; Pilkington \& Walker, 2003).

Taken together, theoretical arguments, current educational policy demands, and empirical evidence form the basis to promote collaborative inquiry learning in science education. In the following, we take a closer look at the meaning of inquiry learning and how its processes can be supported by computerised learning tools.

\section{Characterising collaborative inquiry learning}

Albeit the importance of inquiry learning is widely recognised, it is difficult if not impossible to give a commonly accepted definition (Cuevas, Lee, Hart, \& Deaktor, 2005). Wheeler (2000) complains that the word 'inquiry' is handled rather elastically to fit people's differing worldviews. Notions of inquiry differ along several dimensions, two of which are outlined now. First, different understandings of inquiry may arise from specific objects to be investigated. Arts and humanities, e.g. seek specific kinds of entities, mostly different from physical objects that are quantitatively measured and possibly described by mathematical formalism. For the domain of science learning Quintana, Reiser, et al. (2004, p. 341) define 'inquiry as the process of posing questions and investigating them with empirical data, either through direct manipulation of variables via experiments or by constructing comparisons 
using existing data sets.' We agree and would like to add the remark that 'data' does not necessarily refer only to quantitative data but also to qualitative data. For example, in a $\underline{\text { Co- }}$

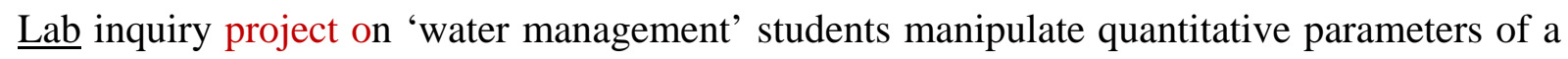
leaking water tank to understand and model its outflow behaviour (Bosler, Bell, \& van Gastel, 2004). In contrast, the subject of ethology draws on observation, classification and interpretation of animal behaviour. This type of qualitative inquiry is supported by the software Animal Landlord (Smith \& Reiser, 1998).

Second, descriptions of inquiry learning choose different degrees of concretion in regard to student activities; three degrees are specified in the following. Some inquiry models, often with a socio-cognitive background, leave a lot of freedom to learner groups to define their own processes when inquiring. The "knowledge building” approach by Scardamalia and Bereiter (1991) describes inquiry as an unpredictable, holistic process of creative development of ideas within a community of learners. Due to the interdisciplinary generality of this approach learning processes are not defined as a set of operations typical for doing research, but more generally as generating, classifying, representing, linking, and annotating elements of knowledge. Consequently, this approach is not only suitable for education, but, e.g. also for the contexts of health care, business and community affairs, etc. (Scardamalia 2004). Inquiry models of another category are more specific about distinct inquiry processes (activities) that students are supposed to go through. Some models even define one or a small number of pathways students should take through the activities. The inquiry cycle by White and Frederiksen (1998), for example, consists of the iterated activity sequence "question predict - experiment - model - apply”; this inquiry cycle is embedded in students' reflective assessment activities.

Further difficulties in defining inquiry learning arise from the fact that inquiry learning can be seen in close relation to problem-based (Evenson \& Hmelo, 2000), project-based (Blumenfeld et al., 1991), or discovery learning (Gijlers \& de Jong, 2005). For instance, 
problem-based learning is described as student-centred activities around a rich problem that affords free inquiry by students (Barrows, 1985; Evenson \& Hmelo, 2000). The greatest correspondences of inquiry learning are probably to project-based learning which 'is a comprehensive perspective focused on teaching by engaging students in investigation. Within this framework, students pursue solutions to nontrivial problems by asking and refining questions, debating ideas, making predictions, designing plans and/or experiments, collecting and analyzing data, drawing conclusions, communicating their ideas and findings to others, asking new questions, and creating artefacts.' (Blumenfeld et al., 1991, p. 371). Referring to Edelson, Gordin, and Pea (1999, p. 394) discovery learning characterises a narrower term: 'In our conception of learning from inquiry, students can discover scientific principles through their own inquiry activities, but discovery is not the only mechanism for learning from inquiry.'

Quintana et al. (2004) divide the processes of inquiry into three broad categories: sense making, which involves basic operations like hypothesis formation or data analysis, process management, which stands for strategies to control the inquiry process, and articulation and reflection which include constructive, evaluative and articulating processes. For our purposes, i.e. tying computerised tools to specific collaborative inquiry learning processes, these categories seem too general. Therefore, we compared recent approaches of science education experts characterising the process of inquiry learning to find out what the approaches have in common. The results of this search are presented in Tables 1 and 2.

Please insert Tables $1 \& 2$ here

The ten groups of investigators (Cuevas et al., 2005; Friedler, Nachmias, \& Linn, 1990; Gijlers \& de Jong, 2005; Harms, Mayer, Hammann, Bayrhuber, \& Kattmann, 2004; Löhner, van Joolingen, Savelsbergh, \& van Hout-Wolters, 2005; National Research Council, 1996; 
Schecker, Fischer, \& Wiesner, 2004; Schwarz \& White, 2005; Singer, Marx, Krajcik, \& Chambers, 2000; Windschitl, 2004) in Tables 1 and 2 were selected to cover a wide range of inquiry processes and terminology. We tried to build a synthesis out of their specifications. By compiling a variety of approaches to inquiry, we determined a set of nine categories that captured the space of ideas about inquiry held by the investigators. The nine categories were labelled as 'main inquiry processes' and are shown in the leftmost columns of our Tables. In Tables 1 and 2, we associated authors' inquiry processes to our nine categories. The processes are not listed in a fixed chronological order: Students may go through the processes in the order needed and return to them if necessary. Analyses of practice have shown that science inquiry can take a variety of forms (McGinn \& Roth, 1999; Windschitl, 2004).

Orienting and asking questions are almost always the first processes of an inquiry. Students make observations or gaze at scientific phenomena that catch their interest or arouse their curiosity. Ideally, they develop questions by themselves. A particular difficulty in a domain to be explored is to formulate "good" questions that are relevant and may be investigated by scientific means. Arriving at good questions may typically take several attempts as insight in the domain grows (cyclic progression of inquiry).

Hypothesis generation is the formulation of relations between variables (de Jong \& Njoo, 1992). Stating a hypothesis is a difficult task for many students. In early stages of the inquiry process, students often do not know which items and quantities to focus on from a scientific point of view. Another problem is that learners and even university students simply do not know what a hypothesis should look like. They do not recognise that it consists of variables and a relation between them and - in many scientific fields - should take the form of an 'ifthen’ statement (de Jong \& van Joolingen, 1998; Njoo \& de Jong, 1993).

Planning in the narrower sense involves the design of an experiment to test the hypothesis and the selection of appropriate measuring instruments for deciding upon the validity of the hypothesis (Harms et al., 2004). In the broader sense, planning also incorporates the use of 
suitable metacognitive strategies. In open inquiry, students are given the opportunity to organise their learning at times independently from the teacher which demands the use of a number of organisation, control, and monitoring strategies termed process management strategies by Quintana et al. (2004) or regulative processes by de Jong (2005).

Investigation as the link to natural phenomena is the empirical aspect of inquiry learning. It includes the use of tools to collect information and data, the implementation of experiments, and the organization of the data pool (Harms et al., 2004). The types of information and data needed are widely different across domains and also depend on whether an investigation is qualitative or quantitative.

Analysis and interpretation of data form the basis of empirical claims and arguments for the proposition of a model (Windschitl, 2004). Frequently, students' interpretation of data results in the confirmation of the current hypothesis even in the face of counter evidence. This phenomenon is known as 'confirmation bias'. Another cognitive hurdle for learners seems to be the interpretation of graphs, e.g. as a result of a computer simulation (de Jong \& van Joolingen, 1998; Mokros \& Tinker, 1987).

Model exploration and creation is a fundamental aspect of science learning (Schwarz \& White, 2005; Windschitl, 2004; Niedderer, Schecker, \& Bethge, 1991). Models are used in science for several purposes (Justi \& Gilbert, 2002). Students should learn to explore, create, test, revise and use externalised scientific models that may express their own internalised mental models (Gilbert \& Boulter, 1998; Gobert, 2000; Gobert \& Tinker, 2004). For our purposes, we define modelling as building a cohering whole of objects and relations in order to represent a target area of reality, to reproduce observations from this area, to predict developments, or even to affect developments in this area. This broad definition includes models in all possible domains created in a variety of formats: crafted objects as models, propositional models, free sketches, formalised graphical models, mathematical models, or software models. 
In conclusion and evaluation activities, students extract the results from their inquiry. Conclusions might be drawn from data and in comparison with models, theories or other experiments (Harms et al., 2004). Evaluation is a reflective process helping students to judge their own research. When students apply their research results to a new problem they learn to evaluate whether the results fit the theory or have to be reconsidered. By evaluating the attributes of each activity and its function in scientific inquiry, students grow to understand the nature of inquiry learning (White \& Frederiksen, 1998).

Communication represents the collaborative element of inquiry learning. Communication is a process that may span all other processes of scientific inquiry starting with the development of a research question and ending with the presentation or reporting of results. A common kind of support to structure communication processes is the use of collaboration scripts (Kollar, Fischer, \& Slotta, 2005). Students learn how to make claims on the basis of data and to provide reasons why the data support their claims. While communicating, the learners are also forced to reflect their own work.

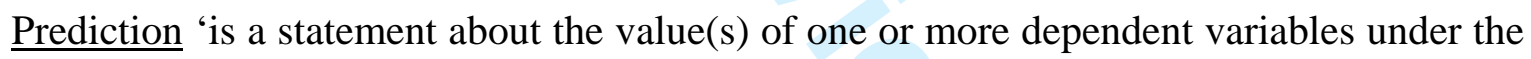
influence of one or more independent variables.' (de Jong \& van Joolingen, 1998, p. 189). In a prediction learners express their beliefs about the dynamics of a system, while in a hypothesis the relations of the variables are emphasised. This last category may also symbolise the unfinished inquiry process after reaching a conclusion where new questions and hypotheses arise from the research results. Therefore, some authors prefer the representation of scientific inquiry in form of a cycle (Schwarz \& White, 2005; Windschitl, 2004).

Tables 1 and 2 show that well-known inquiry conceptions use a series of processes and leave out other processes. The order of our nine main inquiry processes is not fixed, but very likely to be found are orientation and questioning in the beginning, processes of investigation like experimenting in the middle, and finalizing activities like conclusion and evaluation at the end. 
Tools supporting collaborative inquiry learning

There are several arguments based on theory and empirical studies about how computerised tools can support student inquiry. Two very general reasons for the use of computer tools for inquiry have been described in the research literature (e.g. Edelson et al., 1999; van Joolingen, de Jong, Lazonder, Savelsbergh, \& Manlove, 2005; Lehtinen, 2003). First, computer tools help students to focus on higher learning processes being characteristic for inquiry. Computers support learners in planning investigations or constructing knowledge by assuming large parts of routine processes like calculating, acquiring, sorting, or visualising data, retrieving and saving information. Second, the computer system can be controlled by the learners themselves. They can access information and hints via the interface on their own initiative and do not necessarily have to rely on the teacher. Self-regulated learning with all its positive effects on motivation can be realised.

In the first part of this article a collection of inquiry processes was presented, comprising several established accounts of inquiry learning and covering a general notion of scientific inquiry. Starting from this conception of inquiry we now intend to show examples of computerised assistance for processes within this spectrum and to describe their effects on students' learning processes as reported in research literature. Tools from the NetCoIL partners formed the starting point of this collection, complemented by tools from several other learning environments. The tools are collected so that different accounts of inquiry in different domains and all processes in Tables 1 and 2 are covered. Of course, the collection cannot give a complete overview of all tools designed to support the listed processes. Its intention is to show examples of sound development and define a wide scope for integration attempts as carried out, for example, in the NetCoIL project (cf. the concluding section on future challenges). Table 3 gives a brief overview of the tools mentioned in the following and of some research findings on their effects on students' learning processes. 


\section{$\underline{\text { Tools supporting orientation and asking questions }}$}

Computer tools can support processes of orienting and asking questions by catching learners’ interest and curiosity, produce a trade-off between free and guided learning, and provide learners with continuous thought-provoking impulses. Computer environments can facilitate questioning by focusing students' attention to important aspects of the phenomenon under investigation as shown by Hmelo and Day (1999) when evaluating biomedical simulations the 'DxR simulation of Mrs. Buchanan’ - enriched by ‘contextualised questions’.

To arouse students' interest and curiosity several tools covering the whole scope of multimedia applications can be used, presuming that the issue of appealing design is taken into account. Some examples from the Viten learning environment (www.viten.no) suitable at lower secondary level are given. On the basis of classroom trials, Viten projects were and are repeatedly optimised to arouse student interest (Jorde, Strømme, Sorborg, Erlien, \& Mork, 2003). The Viten project 'Bears' uses short introductory text windows illustrated with beautiful photos from nature. Viten’s ‘Earth Processes’ program takes students on a short time travel by way of animations. Another approach has established the extensive use of video material designed like detective novels: the series of the Adventures of Jasper Woodbury for students in grades 5 and up (Cognition and Technology Group at Vanderbilt, 1993, 1997). A videodisk presents an exciting story anchoring a complex and challenging student task. Learners develop problem-solving skills while planning, for example, a complex trip or making business plans.

A balance between freedom and guidance in an inquiry learning environment should give students options to develop their own questions. While orienting, students should be able to get an impression of how the first steps of the investigation could look to make plans. In the

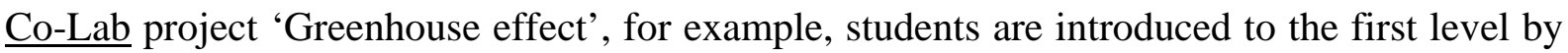
an assignment text that advises them to look around, to experiment with a simplified 
simulation of the sun-and-earth configuration, and to build a simple model of these processes (van Joolingen et al., 2005; www.co-lab.nl; cf. Figures 1 and 3). This gives guidance for first orientation about what to do, but there is still a lot of freedom for learners to develop their own research questions during their investigations.

Please insert Figure 1 about here

Since complex problem fields can not be investigated in just one attempt, structures of the learning environment should allow for continued inquiry. Progressive questioning can be supported, for example, by using the Computer-Supported Intentional Learning Environment (CSILE) or its successor Knowledge Forum (Scardamalia \& Bereiter, 1991; Rahikainen, Lallimo \& Hakkarainen, 2001; Scardamalia, 2004), or software with similar options like Synergeia and FLE3 (Rubens, Emans, Leinonen, Gomez-Skarmeta \& Simons, 2005). They offer a knowledge building tool that enables learners to add their own notes to a communal database. Notes have to be labelled 'question', 'my theory', 'plan', etc. ('thinking types'); scaffolds explaining the characteristics of each thinking type are offered. This way, students are supported in collaborative knowledge building and development of explanations and new questions throughout an ongoing inquiry (Scardamalia, 2002); the tool fosters constructing a joint problem space as opposed to merely individual understanding (Cohen, 1995).

\section{Tools supporting hypothesis generation}

A computer tool specialised in supporting hypothesis generation is the ExplanationConstructor (Sandoval, 2003, Sandoval \& Reiser, 2004). The software provides several windows: The Organizer is used to develop questions and lists titles of corresponding explanations. These are elaborated in detail by the learners in another window. The learners link their explanations to pieces of evidence, i.e. diagrams with data, shown in a third 
window. Further Explanation Guides make the important components of a scientific explanation in a specific field, e.g. in the field of natural selection explicit (Sandoval \& Reiser, 2004). The tool facilitates students' construction of sound causal explanations in the field of evolution, but additional epistemic discourse seems to be necessary to enhance their ideas of the nature of science (Sandoval, 2003).

In order to prepare sound and systematic testing of ideas, students - like scientists - need to assume specific relations between variables. The Hypothesis scratchpad (van Joolingen \& de Jong, 1991), that was also integrated in several learning environments like SimQuest (van Joolingen \& de Jong, 2003) and SMISLE (van Joolingen \& de Jong, 1996), addresses some of the obstacles in hypothesis generation by providing the structure a hypothesis should have. In a recent version of the tool two collaborating students can compose 'if-then' hypotheses using selective lists of variables and qualitative descriptions of their development. In studies, the Hypothesis scratchpad helped learners with their initial exploration of the hypothesis space which resulted in more, better and more explicitly tested hypotheses. Further, the tool made learners more aware of the hypothesis generation process (van Joolingen \& de Jong, 1993). But usability problems led to the development of a Proposition table that offers a list of fully specified hypotheses to be rated with truth-values and tested by the learners (cf. van Joolingen et al., 2005, p. 675).

\section{$\underline{\text { Tools supporting planning }}$}

An option to support planning is to divide complex tasks into an ordered list or an unordered set of activities. Some learning environments, like KIE (Knowledge Integration Environment; Linn, 2000), WISE (Web-based Inquiry Science Environment; Slotta, 2004) and Viten (Jorde et al., 2003), offer an ordered list of events and activities for access via a navigation panel. Students are free to access activities in an order they choose, but the listed order from top to

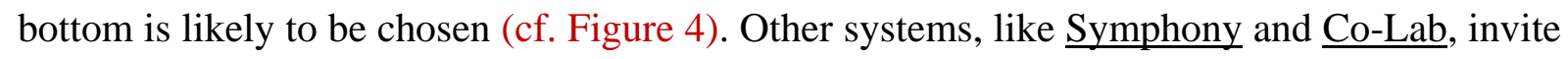


learners to plan deliberately and divide the inquiry process into a manageable set of activities. Based on iterated development and testing, Symphony offers planning support at different levels (Quintana, Eng, Carra, Wu \& Soloway, 1999): The ‘conductor window’ proposes metaprocess activities like revising the plan, doing the next activity, etc. The ‘inquiry map' shows five possible activities: develop problem, collect data, visualise data, model data, and review progress. Activity rationales are explained by rollover guides. Students can plan an investigation by sequencing these activities in a table. And 'flow diagrams' visualise tool use procedures. The $\underline{\mathrm{Co}-\mathrm{Lab}}$ environment provides learners with a process coordinator tool that shows five high-level activities (starting out, modelling and hypothesising, collecting information, drawing conclusions, finishing) as well as subordinate activities along with descriptions and hints (van Joolingen et al., 2005; see Figure 1). Students may work on the steps in the order they choose and can add individual steps and edit them. When a designer or a teacher is setting up a Co-Lab project, the process coordinator's support can and should be faded out over the sequence of project submodules. Manlove, Lazonder, and de Jong (2007) found that regulative support through the process coordinator helped students in tasks like writing lab reports, but not in graphical modelling; it seems even to draw off time from modelling. As a consequence, the authors argue for regulative support that is closely adapted to task activities and interweaved with content support.

Please insert Figure 2 about here

\section{$\underline{\text { Tools supporting investigations }}$}

Studies reveal several difficulties students have with running investigations, e.g. they do not know which variables to focus on, how to conduct conclusive and efficient experiments, and tend to confirm their original hypothesis (de Jong \& van Joolingen, 1998, p. 184-185). 
Computer assistance has the potential to reduce the complexity of phenomena, to focus on a smaller set of items and variables, and to offer a 'model progression' over several levels (van Joolingen et al., 2005). Further measures support successful learning with simulations, among them the use of multiple representations, 'tailorability' of tools (Blake \& Scanlon, 2007), prompting for reflective activities (Pilkington \& Parker-Jones, 1996; White \& Frederiksen, 1998), and interpretative cues (Reid, Zhang, \& Chen, 2003). Some examples of different types of investigation and corresponding tool support are given: In Viten projects, different representations of information are offered within the software environment. The project 'On thin ice' provides an animation showing the basic structures of earth's radiation balance and how it is affected by factors like deforestation, combustion of fossil fuels, traffic, and volcanic eruptions. The animation has text windows on demand. Another animation, complemented by voice information, briefly explains what climate models are and what they can predict. In a following section of the project, students can retrieve time series of averaged data from expert projections. Additionally, the project gives students a short list of appropriate web links where they can deepen the knowledge gained so far. On the whole, $\underline{\text { Viten }}$ stimulates students to collect various types of information by using rich multimedia functionality. A similar approach is taken by WISE.

The $\underline{\mathrm{Co}-\mathrm{Lab}}$ environment has a focus on experimentation and the collection of quantitative data through measurement. The challenge is to reproduce the experimental data through system dynamics modelling. Each $\underline{\text { Co-Lab }}$ submodule offers a phenomenon of a specific type, either a simulation, a remote experiment, or expert datasets. In Co-Lab's 'Water Management' project, for example, students can experiment with a water tank that has a variable in- and outflow of water. At the first level, the water tank is presented as a simulation in which students can vary the tank diameter, the initial tank level, the flow from a tap (inflow) and the hole diameter at the bottom (outflow, see Figure 2). At following levels students can run remote experiments with a real water tank located at the AMSTEL Institute 
in Amsterdam and with more complex models of polders and rivers (model progression). Regulative support for student investigations is delivered via the 'process coordinator' (see above), further experimental support through a lab manual and help files (van Joolingen et al., 2005).

$\underline{\text { Tools supporting analysis and interpretation }}$

Analysis and interpretation processes are carried out in order to check one's own hypotheses against new information and data. For this purpose, it is first necessary to represent data in a format appropriate for analysis. Software environments that put emphasis on data analysis like Cool Modes (Pinkwart, 2005, 2003) and Co-Lab offer graph tools and table tools for the dynamic representation of experimental or modelled datasets (Figures 1 and 2). In addition,

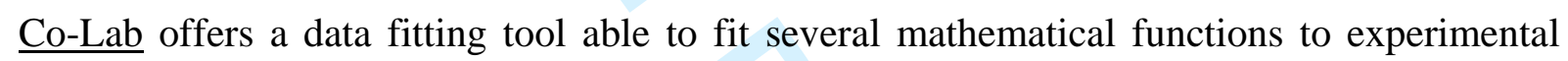
data graphs. Using this tool, students may get an idea of how they could quantitatively model data they gathered in experimentation (van Joolingen, et al., 2005).

The Cool Modes environment additionally supports the interpretation of data in diagrams or tables. Learners are given the option to attach their own notes as handwritten or textual annotations to data windows (Lingnau, Kuhn, Harrer, Hofmann, Fendrich \& Hoppe, 2003). Using multiple workspaces and layers flexibly, Cool Modes can display different tools, e.g. a graph window and a note window, next to or on top of each other. Direct reference to data representations becomes possible and facilitates data interpretation - also in collaborative processes (see Figure 2; Manlove, Lazonder, \& de Jong, 2007). A similar function is available in the software Progress Portfolio (Loh, Radinsky, Russell, Gomez, Reiser \& Edelson, 1998). The tool can be used to document findings like images or data tables and record student understanding and thinking related to the artefacts.

An interesting data analysis feature is implemented in the software Galápagos Finches from the BGuILE curriculum (Reiser, Tabak, Sandoval, Smith, Steinmuller \& Leone, 2001). 
Please insert Figure 3 about here

\section{Tools supporting modelling}

In accordance with the broad definition of modelling given above, several tools can be considered that support modelling at different levels of abstraction. A crucial issue here is to enable modelling at a level accessible to a particular group of learners (Miller, Ogborn, et al., 1993; Webb, 1994) as well as the learners' advancement towards higher abstraction and complexity, e.g. from qualitative to quantitative modelling. The WISE project 'What's in a house?' aims at modelling in terms of crafting a small house that would be energy efficient in a desert environment. The WISE computer environment supports the design process by providing evidence of how plants manage to survive in the desert and by focusing on specific physical characteristics of these plants. Using a text tool, students express their insights in design principles and how they could be realised in a desert house. 
Graphical modelling helps students represent and manipulate abstract and complex concepts and structures (Miller et al., 1993; Niedderer et al., 1991); it can be supported in

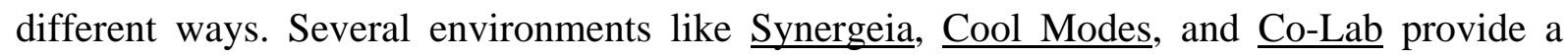
whiteboard function useful for students in developing first ideas for problem solution (Rubens et al., 2005; Lingnau et al., 2003; van Joolingen et al., 2005): Learners may draw sketches and attach annotations in order to represent the problem at a very concrete level. Environments like WISE and $\underline{\text { Cool Modes include mapping tools, similar to the MindManager or the CMap }}$ $\underline{\text { Tools, }}$ which are specialised at constructing and analysing logical structures of terms (concepts). Mapping software helps construct integrated knowledge and retrieve information (Novak, 1990; Novak \& Cañas, 2008). Similarly, the Expert Builder supports students at primary level in visualising and manipulating knowledge and inference structures (Webb, 1994).

In addition to qualitative graphical support, some tools have semi-quantitative and quantitative modelling features. The environments $\underline{\text { Model-It }}^{\mathrm{TM}}$ (Metcalf, Krajcik \& Soloway, 2000), ModelsCreator and its successor ModellingSpace (Avouris, Margaritis, Komis, Saez \& Meléndez, 2003) try to connect closely to everyday objects and terminology to make modelling accessible to young students. For several fields of investigation the software provides palettes of images from everyday objects. ModellingSpace also allows for the creation of new entities represented by photos or even video frames recorded by the user (Papadimitriou, Fiotakis, Stoica, Komis, \& Avouris, 2006). Learners may select or create objects and attach observable variables to them, e.g. the 'water level' to a 'barrel'. They decide which variables affect others and define relations in a semi-quantitative manner choosing from a set of relation graphs or propositional relations. Complex networks of objects and relations can be defined and their behaviour be tested. This type of software provides particularly good support for the first steps of modelling by bridging the gap between real-life objects and scientific concepts (Metcalf et al., 2000; Papadimitriou, Fiotakis, et al., 2006). 
In contrast, system dynamics modelling rests upon the distinction between stock and flow quantities. It requires some domain knowledge and modelling skills from the outset. Stock-

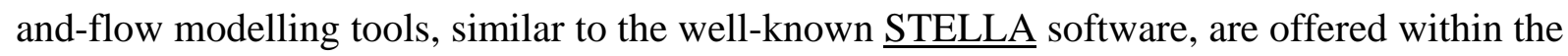

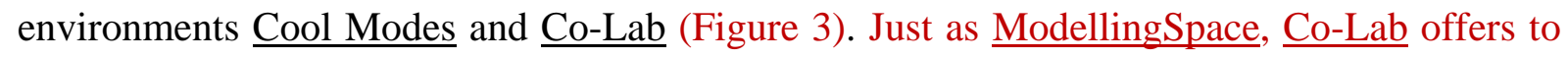
define semi-quantitative model relations first and to enter mathematical relations later (van Joolingen et al., 2005). An ongoing challenge consists in developing environments that allow for as seamless transitions between different types (levels) of modelling as possible. Several studies showed that student modelling needs intensive scaffolding, for example through the teacher (Li, Law, \& Lui, 2006) or content-specific help files (Manlove et al., 2007).

\section{$\underline{\text { Tools supporting conclusion and evaluation }}$}

In the case of software support for reflective processes like conclusion and evaluation, different levels can be distinguished, viz. more elementary levels of data and artefact interpretation or handling (see also the section on analysis and interpretation) and higher levels of reflecting and valuing results in a broader context (Tabak, Sandoval, Smith, Steinmuller, \& Reiser, 1999).

At an elementary level, evaluation can be supported by storing and recovering artefacts generated by the learners in their work processes. This function is provided by the Co-Lab repository, where students' graphical models and experimental datasets can be saved and retrieved (van Joolingen et al., 2005). In the FLE3 environment, students use the WebTop tool to store different items (documents, web links, knowledge building notes, artefacts) and publish them to (parts of) the learning community (Rubens, et al., 2005). Several environments, for example the ThinkerTools, employ reflective tasks to make students evaluate and reflect more deeply and generally (White \& Frederiksen, 1998). The systems

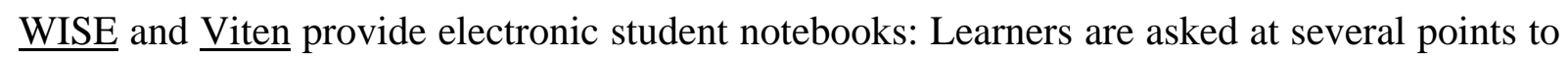
think about questions that challenge them to reflect more deeply, to see things from another 
perspective, or to apply knowledge built in the preceding section. The student answers about the project are saved in the notebook and can be reviewed as a whole at any time by the student or by the teacher for assessment purposes. Viten also allows teachers to give electronic feedback to students via an assessment tool judged helpful by teachers and students (Jorde, et al., 2003). Studies showed that these note tools can support reflective processes, however, the depth of the teacher's interaction with the inquiring students has a clear effect on the degree of knowledge integration (Slotta, 2004). A first illustration for high-level reflective tasks is taken from the WISE project 'Too fast, too furious?' on airbags in car traffic for grades 9-12 (McElhaney \& Linn, 2008). In the first part of the project, students simulate the airbag's and the driver's motion in order to learn about the dangers and conditions of using airbags. At the end of this part, they are asked to review their work on the basis of their notebook. Then, further aspects for reflection are raised: First, students are required to formulate their conclusions on the role of body height, collision speed, and a car's crash zone. In the next activity, the students' assignment is to write a report to the 'Insurance Institute for Highway Safety’ including recommendations for the design of cars and airbags. In a further step, learners are asked to consider different simulations of car crashes and models from other scientific domains and to reflect on general issues of modelling (Figure 4; cf. Slotta, 2004).

Please insert Figure 4 about here

In order to support reflection at a high level, $\underline{\text { Viten }}$ tends to assign a complex, reflective task at the end of a project. In the Viten project 'On thin ice' the final task is to write an article on one of eight topics to be published online for the learning community. The project 'Gene technology' invites students to a role-play debate in a TV discussion program on the topic 'Should we allow gene-modified food in our country?'. Students may choose one of five different positions including the hosts of the discussion program. Some basic arguments as 
well as guidelines and web links for preparation of the discussion are provided. Challenging debates on controversial topics are promising in fostering deep reflection and ensure peer interaction in knowledge construction when sufficiently guided by the teacher (Mork, 2005).

\section{Tools supporting communication}

Admittedly, computer-mediated communication has constraints when compared to face-toface communication, one of the most natural processes for human beings. Although computer technology is constantly progressing, a much narrower stream of a person's messages is transferred and time delays hamper the communicative flow. A chat tool, as, for example, implemented in Co-Lab and in the Cool Modes system (Lingnau et al., 2003), transfers learners utterances as written messages without auditory or other sensory cues of nonverbal communication. Further, written communication is clearly slower than spoken exchange. Communication via a forum, being a central tool in Knowledge Forum (Scardamalia, 2004), has the same characteristics. Some forums work with even greater time delay (see below). Modern technologies like 'voice over IP' or video conferences enrich the message stream with auditory or visual information, thus having the potential to preserve some of the nonverbal parts. Currently they still suffer from narrow bandwidths that slow down the simultaneous transfer of audiovisual data.

Nevertheless, there are significant benefits of computer assistance for communication opening interesting perspectives for learning. First, computer communication is able to avoid biases that might arise e.g. from socioeconomic or ethnic differences or class ranks. Second, it can foster the engagement of some of the more retiring students (Gobert \& Tinker, 2004). Another advantage is that communication via the computer can be logged easily and may be looked up later. Students may resume their prior work processes or enter a discussion at a later point of time. Teachers who are responsible for several learning groups also may use the data asynchronously for coaching or for assessment purposes (Jorde, et al., 2003). The 
asynchronous option eliminates the need to respond to everything immediately and enables parallel processing for students and teachers. Asynchronous work becomes particularly interesting when learning groups at different locations collaborate, possibly even across time zones (Slotta, Jorde, \& Homes, submitted). Restrictions imposed by communication tools may in some cases even be beneficial. It is possible to guide learners by defining requirements for the communicative process. The environment CSILE, its commercial successor $\underline{\text { Knowledge Forum (Scardamalia \& Bereiter, 1991; Scardamalia, 2004) as well as Synergeia }}$ and FLE3 (Rubens et al., 2005) require students to label the type of the message they enter into the forum. This has the potential to yield deeper reflection on the rationale of the ongoing inquiry, but seems to need sufficient practice to be successful (Veermans \& Cesareni, 2005). Further, it was observed that slowed communication, e.g. through a chat tool in Co-Lab, can force learners to focus more clearly on the task they are working on and reduce off-task communication (Sins 2006). Scripted argumentation, e.g. prompted through a script window, is reported to have similar benefits, depending, however, on students' internal scripts and skills (Kollar, Fischer, \& Slotta, 2005, 2007).

In order to cover communication in a broad sense, the notion of 'communication through the artefact' was introduced (Dix, Finlay, Abowd \& Beale, 2004). It is often used in relation to graphical models or maps built by students. We argue that any tool that supports students in constructing, representing and exchanging knowledge enables communication through the artefact. Nevertheless, the graphic format deserves particular attention, since it enables simultaneous processing of large amounts of information (Mayer \& Gallini, 1990). Suthers, Vatrapu, Medina, Joseph, and Dwyer (2008) found positive effects on hypothesis generation and elaboration in asynchronous collaboration when students constructed a 'Knowledge map' graphically associating hypothesis and data statements in addition to threaded discussion. Further, students can use tools for presenting their inquiry results, a specific form of communication. The concept mapping software CMap, for example, includes a presentation 
mode which allows producing slides like in a PowerPoint presentation, e.g. to show the genesis of a concept (Cañas, Coffey, et al. 2003).

\section{Tools supporting prediction}

While there is no doubt that predicting the outcomes of processes will foster deeper understanding, the question is how to avoid students' predictive activities being superficial or simply omitted during inquiry. Some inquiry environments counteract this problem by prompting student prediction on specific issues. In the WISE project 'Too fast, too furious?' on airbags, the central question is how airbag and driver have to be placed so that the inflating airbag causes no harm. This is clarified by generating diagrams of driver and airbag motion in a car crash. After gaining insight into this procedure students are asked to predict the graph of the airbag motion by using a drawing tool. They may then check their prediction using a car crash simulation model that calculates the target graph. The project's predict-observecompare-explain pattern produces learning gains depending on a combination of factors: students' goal-oriented planning, experimentation strategies, and domain knowledge (McElhaney \& Linn, 2008).

While students are still free to choose the sequence in a WISE project, the MAC units (Gobert, Buckley, et al., 2004), now embedded in the control environment Pedagogica, really force them to make predictions at certain points, either in the format of multiple-choice or open-ended questions or graphs. In the $\underline{\text { BioLogica }}^{\mathrm{TM}}$ unit on genetics students learn about genotypes and phenotypes using the fictitious example of dragons (Buckley, Gobert, et al., 2004). In order to test and apply knowledge they have built about 'dragon genetics' the learners are asked to change the allele combinations so that the dragon has two legs, or the task is to change the alleles of a dragon so that its phenotype looks like a comparison dragon; students' comparison is facilitated by dynamically changing figures of the phenotypes. In a comparative study on the use of reasoning types like e.g. cause-to-effect reasoning, students 
who used BioLogica ${ }^{\mathrm{TM}}$ showed higher learning gains than others introduced to genetics in a traditional way (Buckley, Gobert, et al., 2004). In the Pedagogica unit 'Gas laws' one of the students' tasks is to model a bike tyre by using the modelling tool NetLogo that allows building multi-particle models (http://ccl.northwestern.edu/netlogo; Wilensky, 1999; Wilensky \& Resnick, 1999). The simple bike tyre model consists of a container and a variable number of molecules in it that are set in motion by starting the simulation. In order to foster predictive activity, students are asked to install a specific model configuration and to predict what will happen when they run the model. Some unexpected events, like particles evading from the container, may occur (see Figure 5) and cause learners to rethink their model conceptions.

Please insert Figure 5 about here

Please insert Table 3 about here

Challenges for the future

The previous explanations have shown that collaborative inquiry can be characterised by nine main inquiry processes. A wealth of computerised learning tools is available for each of these nine processes. These tools address the important pedagogical issue of helping students handle difficult scientific learning tasks as independently as possible. They also support the teacher who can take care of students with learning difficulties more intensively and give more experienced students a lot of freedom for their own research and testing. However, we also see a number of challenges in the area of collaborative inquiry learning. 
One challenge refers to providing learners with exactly the support they need, i.e. to balance open-ended exploration and guidance for individual learners. A scaffolding measure must be suitable to be effective (Quintana et al., 2004). The level addressed should not be so low that learners obtain no new information. On the other hand, the level must not be so high that the learner cannot integrate the information into his/her knowledge. One option for providing suitable support draws on the use of diagnostic tools. However, well working, continuous diagnostics and related adaptive support need intelligent technical design and consume computational time. A simpler method is to strongly emphasise collaboration in inquiry learning: Students may often be able to support each other. A learner who profited from a tool may, for example, inform other students how it worked. In this case, the diagnosis is performed by the learners themselves, the computer environment only has to support the flexible exchange of information, e.g. via a forum for knowledge building (Scardamalia, 2004) or via a chat function (van Joolingen et al., 2005).

A second challenge consists in the advancement of computer-based learning environments: Structuring learning environments in a way that learners can use the full potential of embedded tools is one issue here. Enabling more flexible learning is another. Flexible learning environments could support the collection of different types of information - quantitative as well as qualitative data. Further, they could enable different kinds of modelling - propositional, graphical, by using formulas -, from which the teacher (or even the students) might choose the most suitable for the lessons. Flexibility in the learning environment makes even more sense when the learning projects also allow several solution pathways. This way, learners may encounter the controversial nature of science. Controversial problems challenge to exchange solutions and therefore are particularly suitable for collaborative inquiry learning (cf. Slotta et al., submitted). The improvement of learning tools, of course, has to be subject to formative and summative evaluation. After all, it is acceptance and effectiveness that decide on using a tool in the classroom. 
We see a third challenge in the integration of different learning environments. Within the frame of the NetCoIL project, researchers and designers of several learning environments cooperate with the aim of using synergies in developing learning tools. Tools that support mainly one inquiry process may be integrated into more comprehensive environments. Integrating, for example, the Hypothesis scratchpad into Co-Lab or a knowledge exchange forum into WISE could fill existing gaps in the learning process support and might prove beneficial (cf. van Joolingen \& de Jong, 2003). When integrating different tools, it must be decided what is technically feasible and, above all, what is desired from a pedagogical perspective. Part of the answer can be given from comparative studies on real inquiry scenarios in the classroom; attempts in this direction were also part of the NetCoIL cooperation (Urhahne, Schanze, et al., submitted). It is not the technical extension of a tool that entails better learning, but a good balance of challenge and support for the learners. Scientific exchange like in the NetCoIL framework sets the stage for meeting the challenges.

\section{References}

Avouris, N., Margaritis, M., Komis, V., Saez, A., \& Meléndez, R. (2003). ModellingSpace: Interaction design and architecture of a collaborative modelling environment. In C. Constantinou (Ed.), Computer Based Learning in Sciences. Proceedings of the Sixth International Conference CBLIS, July 5-10, 2003, Nicosia, Cyprus.

Barrows, H. S. (1985). How to design a problem-based curriculum for the preclinical years. New York, Springer.

Blake, C., \& Scanlon, E. (2007). Reconsidering simulations in science education at a distance: features of effective use. Journal of Computer Assisted Learning, 23(6), 491-502.

Blumenfeld, P. C., Soloway, E., Marx, R. W., Krajcik, J. S., Guzdial, M., \& Palinscar, A. (1991). Motivating project-based learning: sustaining the doing, supporting the learning. Educational Psychologist, 26(3\&4), 369-398. 
Bosler, U., Bell, T., \& van Gastel, L. (2004). Co-Lab: Supporting teacher development of inquiry learning. In D. Zandvliet (Ed.), NARST Conference 2004, Conference Proceedings [CD-ROM]. Vancouver, National Association for Research in Science Teaching.

Buckley, B. C., Gobert, J. D., Kindfield, A. C. H., Horwitz, P., Tinker, R. F., Gerlits, B., Wilensky, U., Dede, C., \& Willett, J. (2004). Model-based teaching and learning with BioLogica $^{\mathrm{TM}}$ : What do they learn? How do they learn? How do we know? Journal of Science Education and Technology, 13(1), 23-41.

Cañas, A. J., Coffey, J. W., Carnot, M. J., Feltovich, P., Hoffman, R. R., Feltovich, J. \& Novak, J. D. (2003). A summary of literature pertaining to the use of concept mapping techniques and technologies for education and performance support (Report for The Chief of Naval Education and Training, Pensacola FL 32500). The Institute for Human and Machine Cognition, Pensacola, FL.

Centre for Educational Research and Innovation (2001). Knowledge and skills for life. First results from PISA 2000. Paris, OECD.

Cognition and Technology Group at Vanderbilt (1993). Anchored instruction and situated cognition revisited. Educational Technology, 33(3), 52-70.

Cognition and Technology Group at Vanderbilt (1997). The Jasper project: Lessons in curriculum, instruction, assessment, and professional development. Hillsdale, NJ, Erlbaum.

Cohen, A. (1995). Mediated collaborative learning - How CSILE supports a shift from knowledge in the head to knowledge in the world. Paper presented at the Annual Meeting of the American Educational Research Association, San Francisco, April 18-22, 1995.

Crook, C. (1991). Computers in the zone of proximal development: implications for evaluation. Computers \& Education, 17, 81-91. 
Cuevas, P., Lee, O., Hart, J., \& Deaktor, R. (2005). Improving science inquiry with elementary students of diverse backgrounds. Journal of Research in Science Teaching, 42(3), 337-357.

de Corte, E., Verschaffel, L., Entwistle, N., \& van Merriënboer, J. (Eds.). (2003). Powerful learning environments. Unravelling basic components and dimensions. Oxford, Elsevier. de Jong, T. (2005). The guided discovery principle in multimedia learning. In R. E. Mayer (Ed.), The Cambridge handbook of multimedia learning (pp. 215-228). New York, Cambridge University Press.

de Jong, T., \& Njoo, M. (1992). Learning and instruction with computer simulations: Learning processes involved. In E. de Corte, M. Linn, H. Mandl, \& L. Verschaffel (Eds.), Computer-based learning environments and problem solving (pp. 411-427). Berlin, Springer.

de Jong, T., \& van Joolingen, W. R. (1998). Scientific discovery learning with computer simulations of conceptual domains. Review of Educational Research, 68(2), 179-201.

de Jong, T., van Joolingen, W., Lazonder, A., Ootes, S., Savelsbergh, E., \& Wilhelm, P. (2002). Co-Lab specifications. Part 1 - Theoretical background (Technical report). Enschede, NL, University of Twente.

Dewey, J. (1910). Science as subject matter and as method. Science, 31, 121-127.

Dewey, J. (1938). Logic: The theory of inquiry. New York, Holt, Rinehart and Winston.

Dillenbourg, P. (1999). What do you mean by collaborative learning? In P. Dillenbourg (Ed.), Collaborative learning: Cognitive and computational approaches (pp. 1-19). Oxford, Elsevier.

Dix, A., Finlay, J., Abowd G., \& Beale R. (2004). Human-computer interaction. Englewood Cliffs, NJ, Prentice Hall. 
Duit, R., \& Treagust, D. (1998). Learning in science: From behaviourisms towards social constructivism and beyond. In B. Fraser \& K. Tobin (Eds.), International handbook of science education (pp. 3-25). Dordrecht, Kluwer.

Edelson, D. C. (2001). Learning-for-use: A framework for the design of technology-supported inquiry activities. Journal of Research in Science Teaching, 38(3), 355-385.

Edelson, D. C., Gordin, D. N., \& Pea, R. D. (1999). Addressing the challenges of inquirybased learning through technology and curriculum design. Journal of the Learning Sciences, 8(3\&4), 391-450.

Evenson, D. H., \& Hmelo, C. (Eds.). (2000). Problem-based learning. A research perspective on learning interactions. Mahwah, NJ, Erlbaum.

Friedler, Y., Nachmias, R., \& Linn, M. C. (1990). Learning scientific reasoning skills in microcomputer-based laboratories. Journal of Research in Science Teaching, 27(2), 173191.

Gilbert, J., \& Boulter, C. (1998). Learning science through models and modelling. In B. Fraser \& K. Tobin (Eds.), International handbook of science education (pp. 52-66). Dordrecht, Kluwer.

Gijlers, H., \& de Jong, T. (2005). The relation between prior knowledge and students' collaborative discovery learning processes. Journal of Research in Science Teaching, 42(3), 264-282.

Gobert, J. D., \& Buckley, B., et al. (2004). Modeling Across the Curriculum (MAC): Technology, Pedagogy, Assessment, \& Research. Paper presented at the Conference of the American Educational Research Association 2004, San Diego, CA.

Gobert, J. D., \& Tinker, R. F. (2004). Introduction to the Issue. Journal of Science Education and Technology, 13(1), 1-5.

Gobert, J. D. (2000). Introduction to model-based teaching and learning in science education. International Journal of Science Education, 22(9), 891-894. 
Greeno, J. G., Collins, A. M., \& Resnick, L. B. (1996). Cognition and learning. In D. C. Berliner \& R. C. Calfee (Eds.), Handbook of educational psychology (pp. 15-46). New York, Macmillan.

Harms, U., Mayer, R. E., Hammann, M., Bayrhuber, H., \& Kattmann, U. (2004). Kerncurriculum und Standards für den Biologieunterricht in der gymnasialen Oberstufe [Core curriculum and standards for biology at the Gymnasium secondary level II]. In H.E. Tenorth (Ed.), Kerncurriculum Oberstufe II. Biologie, Chemie, Physik, Geschichte, Politik (pp. 22-84). Weinheim, Beltz.

Henning, P. H. (2004). Everyday cognition and situated learning. In D. H. Jonassen (Ed.), Handbook of research on educational communications and technology (2nd ed., pp. 143168). Mahwah, NJ, Erlbaum.

Hmelo, C., \& Day, R. (1999). Contextualized questioning to scaffold learning from simulations. Computers \& Education, 32, 151-164.

Horwitz, P. (2005). Performance assessment: Science knowledge in action. @Concord 9(1), 8-9.

Jorde, D., Strømme, A., Sorborg, Ø., Erlien, W., \& Mork, S. M. (2003, October). Virtual environments in science - Viten.no. Report no. 17 of the network for IT research and competence in education (ITU). Retrieved August 28, 2008, from http://www.itu.no/Dokumenter/Rapporter/1066214309.29/view.

Justi, R. S., \& Gilbert, J. K. (2002). Modelling, teachers' views on the nature of modelling, and implications for the education of modellers. International Journal of Science Education, 24(4), 369-387.

Kollar, I., Fischer, F., \& Slotta, J. D. (2007). Internal and external scripts in computersupported collaborative inquiry learning. Learning and Instruction, 17(6), 708-721.

Kollar, I., Fischer, F., \& Slotta, J. D. (2005). Internal and external collaborative scripts in web-based science learning at schools. In T. Koschmann, D. Suthers, \& T. W. Chan 
(Eds.), Computer supported collaborative learning 2005: The next 10 years! (pp. 331340). Mahwah, NJ, Erlbaum.

Koschmann, T. (Ed.). (1996). CSCL: Theory and practice of an emerging paradigm. Hillsdale, NJ, Lawrence Erlbaum.

Koschmann, T., Hall, R., \& Miyake, N. (Eds.). (2001). CSCL 2 carrying forward the conversation. Mahwah, NJ, Lawrence Erlbaum.

Lehtinen, E. (2003). Computer-supported collaborative learning: an approach to powerful learning environments. In E. de Corte, L. Verschaffel, N. Entwistle, \& J. van Merrienboer (Eds.), Powerful learning environments: Unravelling basic components and dimensions (pp. 35-53). Oxford, Elsevier Science.

Li, S. C., Law, N., \& Lui, K. F. A. (2006). Cognitive perturbation through dynamic modelling: a pedagogical approach to conceptual change in science. Journal of Computer Assisted Learning, 22(6), 405-422.

Lingnau, A., Kuhn, M., Harrer, A., Hofmann, D., Fendrich, M., \& Hoppe, H. U. (2003). Enriching traditional classroom scenarios by seamless integration of interactive media. In V. Devedzic, J. Spector, D. Sampson, \& Kinshuk (Eds.). Advanced learning technologies: Technology enhanced learning (pp. 135-139). Los Alamitos, CA, IEEE Computer Society. Linn, M. C. (2000). Designing the knowledge integration environment. International Journal of Science Education, 22(8), 781-796.

Loh, B., Radinsky, J., Russell, E., Gomez, L. M., Reiser, B. J., \& Edelson, D. C. (1998). The progress portfolio: Designing reflective tools for a classroom context. In C. Karat et al. (Eds.), Proceedings of CHI 98 conference on human factors in computing systems (pp. 627-634). Reading, MA, Addison-Wesley.

Löhner, S., van Joolingen, W. R., Savelsbergh, E. R., \& van Hout-Wolters, B. (2005). Students' reasoning during modeling in an inquiry learning environment. Computers in Human Behavior, 21, 441-461. 
Manlove, S., Lazonder, A. W., \& de Jong, T. (2007). Software scaffolds to promote regulation during scientific inquiry learning. Metacognition and Learning, 2, 141-155.

Mayer, R. E., \& Gallini, J. K. (1990). When is an illustration worth ten thousand words? Journal of Educational Psychology, 82(4), 715-726.

McElhaney, K. W., \& Linn, M. C. (2008). Impacts of students' experimentation using a dynamic visualization on their understanding of motion. International Perspectives in the Learning Sciences: Creating a Learning World. Proceedings of the 8th International Conference of the Learning Sciences. International Society of the Learning Sciences Inc., Utrecht, The Netherlands.

McGinn, M., \& Roth, W.-M. (1999). Preparing students for competent scientific practice: Implications of recent research in science and technology studies. Educational Researcher, 28(3), 14-24.

Metcalf, S. J., Krajcik, J., \& Soloway, E. (2000). Model-It: A design retrospective. In M. J. Jacobson \& R. B. Kozma (Eds.) Innovations in science and mathematics education (pp. 77-115). Mahwah, NJ, Erlbaum.

Miller, R., Ogborn, J., Briggs, J., Brough, D., Bliss, J., Boohan, R., Brosnan, T., Mellar, H., \& Sakonidis, B. (1993). Educational tools for computational modelling. Computers \& Education, 21(3), 205-261.

Mokros, J. R., \& Tinker, R. F. (1987). The impact of microcomputer based labs on children's ability to interpret graphs. Journal of Research in Science Teaching, 24(4), 369-383.

Mork, S. M. (2005). Argumentation in science lessons: Focusing on the teacher's role. Nordic Studies in Science Education, 1(1), 17-30.

National Research Council (1996). National science education standards. Washington, DC, National Academy Press.

Niedderer, H., Schecker, H., \& Bethge, T. (1991). The role of computer-aided modelling in learning physics. Journal of Computer Assisted Learning, 7(2), 84-95. 
Njoo, M., \& de Jong, T. (1993). Exploratory learning with a computer simulation for control theory: Learning processes and instructional support. Journal of Research in Science Teaching, 30(8), 821-844.

Novak, J. D. \& Cañas, A. J. (2008). The Theory Underlying Concept Maps and How to Construct Them, Technical Report IHMC CmapTools 01-2006, Revised 01-2008, Florida Institute for Human and Machine Cognition; retrieved from http://cmap.ihmc.us/Publications/ResearchPapers/TheoryUnderlyingConceptMaps.pdf on August 28, 2008.

Novak, J. (1990). Concept mapping: a useful tool for science education. Journal of Research in Science Teaching 27 (10), 937-949.

Papadimitriou, I. Fiotakis, G., Stoica, A., Komis, V., \& Avouris, N. (2006). Bridging the gap between physical and abstract worlds: Capturing observed phenomena in abstract models through ModellingSpace. Proc. ICALT 2006, Kerkrade, Netherlands, 301-305.

Piaget, J. (1926). The child's conception of the world. Paris, Alcan.

Pilkington, R. M. (2004). Developing discussion for learning (Guest Editorial). Journal of Computer Assisted Learning, 20, Special Issue, 161-164.

Pilkington, R. M., \& Walker, S. A. (2003). Facilitating Debate in Networked Learning: Reflecting on Online Synchronous Discussion in Higher Education. Instructional Science, 31(1\&2), 41-63.

Pilkington, R., \& Parker-Jones, C. (1996). Interacting with computer-based simulation: The role of dialogue. Computers \& Education, 27(1), 1-14.

Pinkwart, N. (2005). Collaborative Modeling in Graph Based Environments. Berlin (Germany), dissertation.de.

Pinkwart, N. (2003). A Plug-In Architecture for Graph Based Collaborative Modeling Systems. In U. Hoppe, F. Verdejo, \& J. Kay (Eds.), Shaping the Future of Learning 
through Intelligent Technologies. Proceedings of the 11th Conference on Artificial Intelligence in Education (p. 535-536). Amsterdam (The Netherlands), IOS Press.

Quintana, C., Eng, J., Carra, A., Wu, H., \& Soloway, E. (1999). Symphony: A case study in extending learner-centered design through process-space analysis. Proceedings of CHI 99 conference on human factors in computing systems (pp. 473-480). Reading, MA, Addison-Wesley.

Quintana, C., Reiser, B. J., Davis, E. A., Krajcik, J. S., Fretz, E., Duncan, R. G., Kyza, E., Edelson, D., \& Soloway, E. (2004). A scaffolding design framework for software to support science inquiry. Journal of the Learning Sciences, 13(3), 337-386.

Rahikainen, M., Lallimo, J., \& Hakkarainen, K. (2001). Progressive inquiry in CSILE environment: teacher guidance and students' engagement. In P. Dillenbourg et al. (Eds.), European perspectives on computer-supported collaborative learning. Proceedings of the first European conference on CSCL (pp. 520-528). Maastricht, Maastricht McLuhan Institute.

Reid, D. J., Zhang, J., \& Chen, Q. (2003). Supporting scientific discovery learning in a simulation environment. Journal of Computer Assisted Learning, 19(1), 9-20.

Reiser, B. J., Tabak, I., Sandoval, W. A., Smith, B. K., Steinmuller, F., \& Leone, A. J. (2001). BGuILE: Strategic and conceptual scaffolds for scientific inquiry in biology classrooms. In S. M. Carver \& D. Klahr (Eds.), Cognition and instruction: Twenty five years of progress (pp. 263-305). Mahwah, NJ, Erlbaum.

Renkl, A., Mandl, H., \& Gruber, H. (1996). Inert knowledge: Analyses and remedies. Educational Psychologist, 31(2), 115-121.

Rubens, W., Emans, B., Leinonen, T., Gomez-Skarmeta, A., \& Simons, R.-J. (2005). Design of web-based collaborative learning environments. Translating the pedagogical learning principles to human computer interface. Computers \& Education, 45, 276-294. 
Sandoval, W. A. (2003). Conceptual and epistemic aspects of students' scientific explanations. The Journal of the Learning Sciences, 12, 5-51.

Sandoval, W. A., \& Reiser, B. J. (2004). Explanation-driven inquiry: Integrating conceptual and epistemic support for scientific inquiry. Science Education, 88, 345-372.

Scardamalia, M. (2004). CSILE/Knowledge Forum ${ }^{\circledR}$. In Education and technology: An encyclopedia (pp. 183-192). Santa Barbara, ABC-CLIO.

Scardamalia, M. (2002). Collective responsibility for the advancement of knowledge. In B. Smith (Ed.), Liberal education in a knowledge society (pp. 67-98). Chicago, Open Court.

Scardamalia, M., \& Bereiter, C. (1991). Higher levels of agency for children in knowledge building: A challenge for the design of new knowledge media. Journal of the Learning Sciences, 1, 37-68.

Schecker, H., Fischer, H. E., \& Wiesner, H. (2004). Physikunterricht in der gymnasialen Oberstufe [Physics education at the Gymnasium secondary level II]. In H.-E. Tenorth (Ed.), Kerncurriculum Oberstufe II. Biologie, Chemie, Physik, Geschichte, Politik (pp. 148-234). Weinheim, Beltz.

Schwarz, C. V., \& White, B. Y. (2005). Metamodeling knowledge: developing students' understanding of scientific modeling. Cognition and Instruction, 23(2), 165-205.

Sekretariat der Ständigen Konferenz der Kultusminister der Länder in der Bundesrepublik Deutschland (Ed.) (2005). Bildungsstandards im Fach Physik für den Mittleren Schulabschluss [Physics education standards for middle school graduation]. Neuwied, Luchterhand.

Singer, J., Marx, R. W., Krajcik, J. S., \& Chambers, J. C. (2000). Constructing extended inquiry projects: Curriculum materials for science education reform. Educational Psychologist, 35(3), 165-178.

Sins, P. H. M. (2006). Students' reasoning during computer-based scientific modeling. Dissertation at the Graduate School of Teaching and Learning, University of Amsterdam. 
Slotta, J. D., Jorde, D., \& Holmes, J. (submitted). Learning from our peers in international exchanges: When is worth doing, and how can we help it succeed?

Slotta, J. D. (2004). The web-based inquiry science environment (WISE): Scaffolding knowledge integration in the science classroom. In M. C. Linn, E. A. Davis, \& P. Bell (Eds.), Internet environments for science education (pp. 203-231). Mahwah, NJ, Erlbaum.

Smith, B. K., \& Reiser, B. J. (1998). National Geographic unplugged: Classroom-centered design of interactive nature films. In C. Karat, A. Lund, J. Coutaz, \& J. Karat (Eds.), Proceedings of CHI 98 conference on human factors in computing systems (pp. 424-431). Reading, MA, Addison-Wesley.

Strijbos, J. W., Kirschner, P. A., \& Martens, R. L. (Eds.). (2004). What we know about CSCL: And implementing it in higher education. Boston, MA, Kluwer Academic Publishers.

Suthers, D. D., Vatrapu, R., Medina, R., Joseph, S., \& Dwyer, N. (2008). Beyond threaded discussion: Representational guidance in asynchronous collaborative learning environments. Computers \& Education, 50(4), 1103-1127.

Tabak, I., Sandoval, W. A., Smith, B. K., Steinmuller, F., \& Reiser, B. J. (1999). Reflection as a vehicle toward local and global understanding. Paper presented at the Annual Meeting of the American Educational Research Association, Montreal, April 1999.

Urhahne, D., Schanze, S., Bell, T., Mansfield, A., \& Holmes, J. (submitted). Computerassisted collaborative inquiry learning in the classroom: the role of the teacher and design implications.

van Joolingen, W. R., \& de Jong, T. (1991). Supporting hypothesis generation by learners exploring an interactive computer simulation. Instructional Science, 20, 389-404.

van Joolingen, W. R., \& de Jong, T. (1993). Exploring a domain through a computer simulation: traversing variable and relation space with the help of a hypothesis scratchpad. In D. Towne, T. de Jong \& H. Spada (Eds.), Simulation-based experiential learning (pp. 191-206). (NATO ASI series). Berlin, Springer. 
van Joolingen, W. R., \& de Jong, T. (1996). Design and implementation of simulation-based discovery environments: the SMISLE solution. Journal of Artificial Intelligence and Education, 7, 253-277.

van Joolingen, W. R., \& de Jong, T. (2003). SimQuest: Authoring educational simulations. In T. Murray, S. Blessing, \& S. Ainsworth (Eds.), Authoring tools for advanced technology educational software: Toward cost-effective production of adaptive, interactive, and intelligent educational software (pp. 1-31). Dordrecht, Kluwer Academic Publishers.

van Joolingen, W. R., de Jong, T., Lazonder, A. W., Savelsbergh, E. R., \& Manlove, S. (2005). Co-Lab: research and development of an online learning environment for collaborative scientific discovery learning. Computers in Human Behavior, 21(4), 671688.

Veermans, M., Cesareni, D. (2005). The nature of the discourse in web-based collaborative learning environments: Case studies from four different countries. Computers \& Education, 45, 316-336.

Vygotsky, L. S. (1978). Mind in society: The development of higher psychological processes. Cambridge, MA, Harvard University Press.

Webb, M. E. (1994). Beginning computer-based modelling in primary schools. Computers \& Education, 22(1-2), 129-144.

Wheeler, G. (2000). The three faces of inquiry. In J. Minstrell \& E. H. van Zee (Eds.), Inquiring into inquiry learning and teaching in science (pp. 14-19). Washington, DC, American Association for the Advancement of Science.

White, B. Y., \& Frederiksen, J. R. (1998). Inquiry, modeling, and metacognition: Making science accessible to all students. Cognition and Instruction, 16(1), 3-118.

Whitehead, A. N. (1929). The aims of education. New York, NY, Macmillan. Wilensky, U. (1999). NetLogo. Center for connected learning and computer-based modeling. Evanston, IL, Northwestern University. 
Wilensky, U., \& Resnick, M. (1999). Thinking in levels: A dynamic systems approach to making sense of the world. Journal of Science Education and Technology, 8(1), 3-19.

Windschitl, M. (2004). Folk theories of "inquiry": How preservice teachers reproduce the discourse and practices of an atheoretical scientific method. Journal of Research in Science Teaching, 41(5), 481-512. 
Collaborative inquiry learning

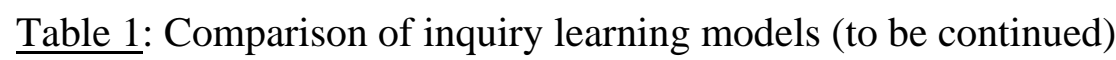

\begin{tabular}{|c|c|c|c|c|c|}
\hline $\begin{array}{l}\text { Main inquiry } \\
\text { processes }\end{array}$ & $\begin{array}{l}\text { Cuevas, Lee, } \\
\text { Hart \& } \\
\text { Deaktor, } 2005\end{array}$ & $\begin{array}{l}\text { Friedler, } \\
\text { Nachmias \& } \\
\text { Linn, } 1990\end{array}$ & $\begin{array}{l}\text { Gijlers \& de } \\
\text { Jong, } 2005\end{array}$ & $\begin{array}{l}\text { Löhner, van } \\
\text { Joolingen, } \\
\text { Savelsbergh \& } \\
\text { van Hout- } \\
\text { Wolters, } 2005\end{array}$ & $\begin{array}{l}\text { Schwarz \& } \\
\text { White, } 2005\end{array}$ \\
\hline $\begin{array}{l}\text { orientation / } \\
\text { question }\end{array}$ & questioning & $\begin{array}{l}\text { define a } \\
\text { scientific } \\
\text { problem }\end{array}$ & $\begin{array}{l}\text { analysis / } \\
\text { orientation }\end{array}$ & orientation & question \\
\hline $\begin{array}{l}\text { hypothesis } \\
\text { generation }\end{array}$ & & $\begin{array}{l}\text { state a } \\
\text { hypothesis }\end{array}$ & $\begin{array}{l}\text { hypothesis } \\
\text { generation }\end{array}$ & hypothesis & hypothesize \\
\hline planning & planning & $\begin{array}{l}\text { design an } \\
\text { experiment }\end{array}$ & planning & & \\
\hline investigation & implementing & $\begin{array}{l}\text { observe and } \\
\text { collect data }\end{array}$ & $\begin{array}{l}\text { testing / } \\
\text { monitoring }\end{array}$ & experiment & investigate \\
\hline $\begin{array}{l}\text { analysis / } \\
\text { interpretation }\end{array}$ & & $\begin{array}{l}\text { analyze and } \\
\text { interpret data }\end{array}$ & $\begin{array}{l}\text { data } \\
\text { interpretation }\end{array}$ & & analyze \\
\hline model & & & & & model \\
\hline $\begin{array}{l}\text { conclusion / } \\
\text { evaluation }\end{array}$ & concluding & $\begin{array}{l}\text { apply the } \\
\text { results }\end{array}$ & evaluation & conclusion & evaluate \\
\hline communication & reporting & & & & \\
\hline prediction & & $\begin{array}{l}\text { make } \\
\text { predictions }\end{array}$ & & & \\
\hline
\end{tabular}


Table 2: Comparison of inquiry learning models

\begin{tabular}{|c|c|c|c|c|c|}
\hline $\begin{array}{l}\text { Main inquiry } \\
\text { processes }\end{array}$ & $\begin{array}{l}\text { Harms, Mayer, } \\
\text { Hammann, } \\
\text { Bayrhuber \& } \\
\text { Kattmann, } \\
2004\end{array}$ & $\begin{array}{l}\text { National } \\
\text { Research } \\
\text { Council, } 1996\end{array}$ & $\begin{array}{l}\text { Schecker, } \\
\text { Fischer \& } \\
\text { Wiesner, } 2004\end{array}$ & $\begin{array}{l}\text { Singer, Marx, } \\
\text { Krajcik \& } \\
\text { Chambers, } \\
2000\end{array}$ & $\begin{array}{l}\text { Windschitl, } \\
2004\end{array}$ \\
\hline $\begin{array}{l}\text { orientation / } \\
\text { question }\end{array}$ & $\begin{array}{l}\text { formulate } \\
\text { questions }\end{array}$ & $\begin{array}{l}\text { making } \\
\text { observations / } \\
\text { posing } \\
\text { questions }\end{array}$ & & $\begin{array}{l}\text { asking } \\
\text { questions }\end{array}$ & $\begin{array}{l}\text { observe } \\
\text { phenomena / } \\
\text { develop } \\
\text { question }\end{array}$ \\
\hline $\begin{array}{l}\text { hypothesis } \\
\text { generation }\end{array}$ & & & $\begin{array}{l}\text { negotiate } \\
\text { hypothesis }\end{array}$ & & $\begin{array}{l}\text { create } \\
\text { hypothesis }\end{array}$ \\
\hline planning & $\begin{array}{l}\text { planning } \\
\text { experiment }\end{array}$ & $\begin{array}{l}\text { planning } \\
\text { investigations }\end{array}$ & $\begin{array}{l}\text { plan and design } \\
\text { experiment }\end{array}$ & & $\begin{array}{l}\text { design } \\
\text { investigation }\end{array}$ \\
\hline investigation & $\begin{array}{l}\text { conduct } \\
\text { experiment }\end{array}$ & $\begin{array}{l}\text { using tools to } \\
\text { gather data }\end{array}$ & $\begin{array}{l}\text { conduct } \\
\text { experiment }\end{array}$ & $\begin{array}{l}\text { data collection, } \\
\text { organization }\end{array}$ & $\begin{array}{l}\text { conduct } \\
\text { investigation }\end{array}$ \\
\hline $\begin{array}{l}\text { analysis / } \\
\text { interpretation }\end{array}$ & $\begin{array}{l}\text { analysis / } \\
\text { interpretation }\end{array}$ & $\begin{array}{l}\text { analyze and } \\
\text { interpret data }\end{array}$ & $\begin{array}{l}\text { analysis / } \\
\text { interpretation / } \\
\text { discussion }\end{array}$ & analysis & $\begin{array}{l}\text { analyze data / } \\
\text { connect } \\
\text { evidence and } \\
\text { claim }\end{array}$ \\
\hline model & & & & & model \\
\hline $\begin{array}{l}\text { conclusion / } \\
\text { evaluation }\end{array}$ & conclusions & $\begin{array}{l}\text { proposing } \\
\text { answers, } \\
\text { explanations }\end{array}$ & $\begin{array}{l}\text { application to a } \\
\text { new problem }\end{array}$ & & \\
\hline communication & communicating & $\begin{array}{l}\text { communicating } \\
\text { the results }\end{array}$ & presentation & $\begin{array}{l}\text { sharing and } \\
\text { communicating } \\
\text { data }\end{array}$ & \\
\hline prediction & & $\begin{array}{l}\text { proposing } \\
\text { predictions }\end{array}$ & $\begin{array}{l}\text { new } \\
\text { hypotheses }\end{array}$ & & $\begin{array}{l}\text { new questions } \\
\text { arise }\end{array}$ \\
\hline
\end{tabular}




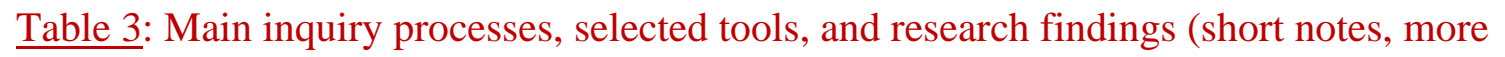
details can be found in the text)

\begin{tabular}{|c|c|c|}
\hline $\begin{array}{l}\text { Main inquiry } \\
\text { processes }\end{array}$ & $\begin{array}{l}\text { Exemplary tools supporting the } \\
\text { inquiry process }\end{array}$ & $\begin{array}{l}\text { Short notes on some research findings on } \\
\text { beneficial effects of tools }\end{array}$ \\
\hline $\begin{array}{l}\text { orientation / } \\
\text { question }\end{array}$ & $\begin{array}{l}\text { Viten } \\
\text { Adventures of Jasper } \\
\text { Woodbury } \\
\text { 'contextualised questions' } \\
\text { CSILE / Knowledge Forum } \\
\text { Synergeia; FLE3 }\end{array}$ & $\begin{array}{l}\text { - arouse interest, motivation (Jorde et al., 2003; } \\
\text { CTG at Vanderbilt, 1993, 1997) } \\
\text { - focus attention (Hmelo \& Day, 1999) } \\
\text { - construct joint problem space (Cohen, 1995; } \\
\text { Scardamalia, 2002, 2004) } \\
\text { - enable progressive questioning (Rahikainen et al., } \\
\text { 2001) }\end{array}$ \\
\hline $\begin{array}{l}\text { hypothesis } \\
\text { generation }\end{array}$ & $\begin{array}{l}\text { ExplanationConstructor } \\
\text { Hypothesis scratchpad } \\
\text { Proposition table }\end{array}$ & $\begin{array}{l}\text { - facilitate causal explanation (Sandoval, 2003; } \\
\text { Sandoval \& Reiser, 2004) } \\
\text { - facilitate exploration of hypothesis space (van } \\
\text { Joolingen \& de Jong, 1993) }\end{array}$ \\
\hline planning & $\begin{array}{l}\text { ordered-list navigation (KIE, } \\
\text { WISE, Viten) } \\
\text { Symphony’s conductor } \\
\text { window, process map, and } \\
\text { flow diagrams } \\
\text { Co-Lab’s process coordinator }\end{array}$ & $\begin{array}{l}\text { - suggests a learning pathway (Slotta, 2004; Jorde } \\
\text { et al., 2003) } \\
\text { - support needed at different levels of planning } \\
\text { (Quintana et al., 1999) } \\
\text { - planning support should be interwoven with } \\
\text { content issues (Manlove et al., 2007) }\end{array}$ \\
\hline investigation & $\begin{array}{l}\text { Viten; WISE } \\
\text { SimQuest } \\
\text { SMISLE } \\
\text { Co-Lab } \\
\text { ExplanationConstructor }\end{array}$ & $\begin{array}{l}\text { support measures: } \\
\text { - multiple representations (Blake \& Scanlon, 2007) } \\
\text { - prompts for reflection (Pilkington \& Parker- } \\
\text { Jones, 1996; White \& Frederiksen, 1998) } \\
\text { - interpretative cues (Reid et al., 2003) } \\
\text { - reduced initial complexity, model progression } \\
\text { (van Joolingen et al.. 2005) }\end{array}$ \\
\hline $\begin{array}{l}\text { analysis / } \\
\text { interpretation }\end{array}$ & $\begin{array}{l}\text { Cool Modes’ graph \& table } \\
\text { tools } \\
\text { Cool Modes’ annotation tool } \\
\text { Co-Lab’s data fitting } \\
\text { Progress Portfolio } \\
\text { Galapagos Finches' data query }\end{array}$ & $\begin{array}{l}\text { - notes in appropriate format attached to objects } \\
\text { facilitate analysis (Manlove et al., 2007) } \\
\text { - reduced routine work (van Joolingen et al., 2005) } \\
\text { - provided data query patterns (Reiser et al., 2001) }\end{array}$ \\
\hline model & $\begin{array}{l}\text { WISE } \\
\text { whiteboards (e.g. Synergeia; } \\
\text { Cool Modes) } \\
\text { mapping tools (Mind Manager; } \\
\text { CMAP; ExpertBuilder) } \\
\text { Model-It'TM; ModellingSpace } \\
\text { system dynamics modelling } \\
\text { (STELLA, Co-Lab, etc.) }\end{array}$ & $\begin{array}{l}\text { - level of model abstraction has to fit learners’ } \\
\text { abilities (Miller et al., 1993; Webb, 1994) } \\
\text { - everyday objects facilitate first modelling steps } \\
\text { (Avouris et al., 2003; Papadimitriou et al., 2006; } \\
\text { Metcalf et al., 2000) } \\
\text { - graphical modelling makes abstract concepts } \\
\text { accessible (Miller et al., 1993; Niedderer et al., } \\
\text { 1991) } \\
\text { - mapping helps construct and retrieve integrated } \\
\text { knowledge (Novak, 1990) } \\
\text { - content-specific support is needed (Li et al., } \\
\text { 2006; Manlove et al., 2007) }\end{array}$ \\
\hline
\end{tabular}


Collaborative inquiry learning

\section{Figure 1}

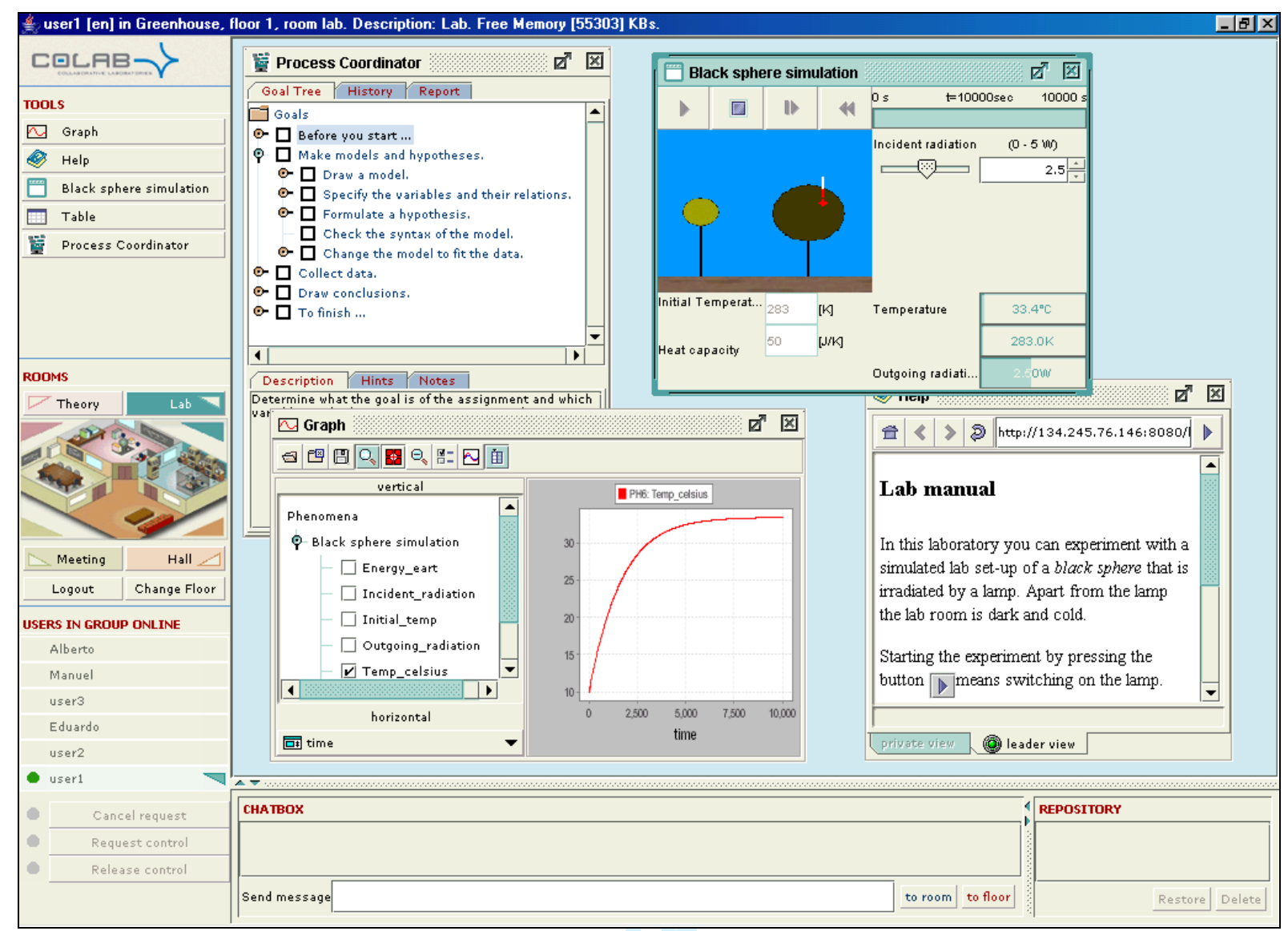


Figure 2

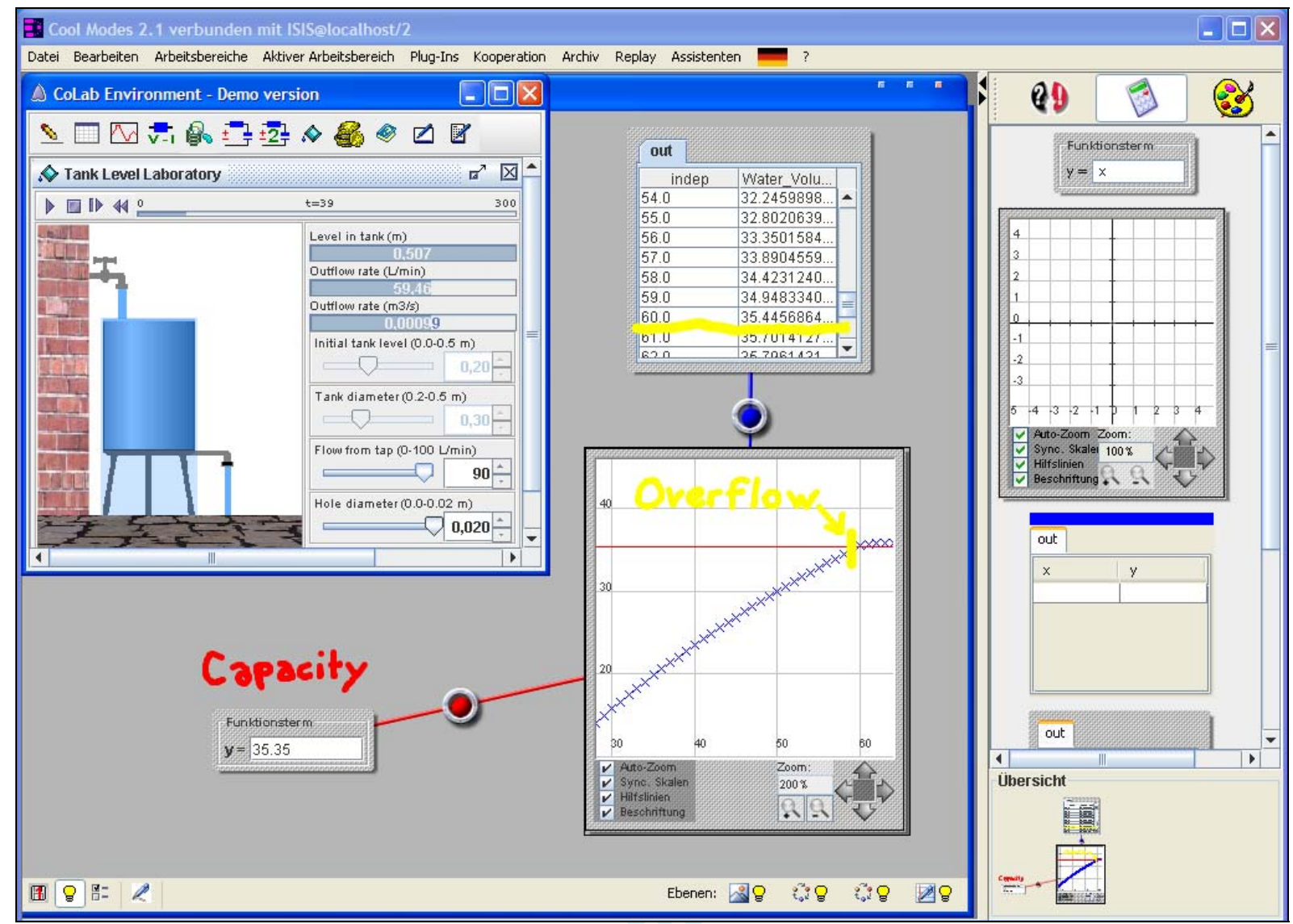


Collaborative inquiry learning

$\underline{\text { Figure } 3}$

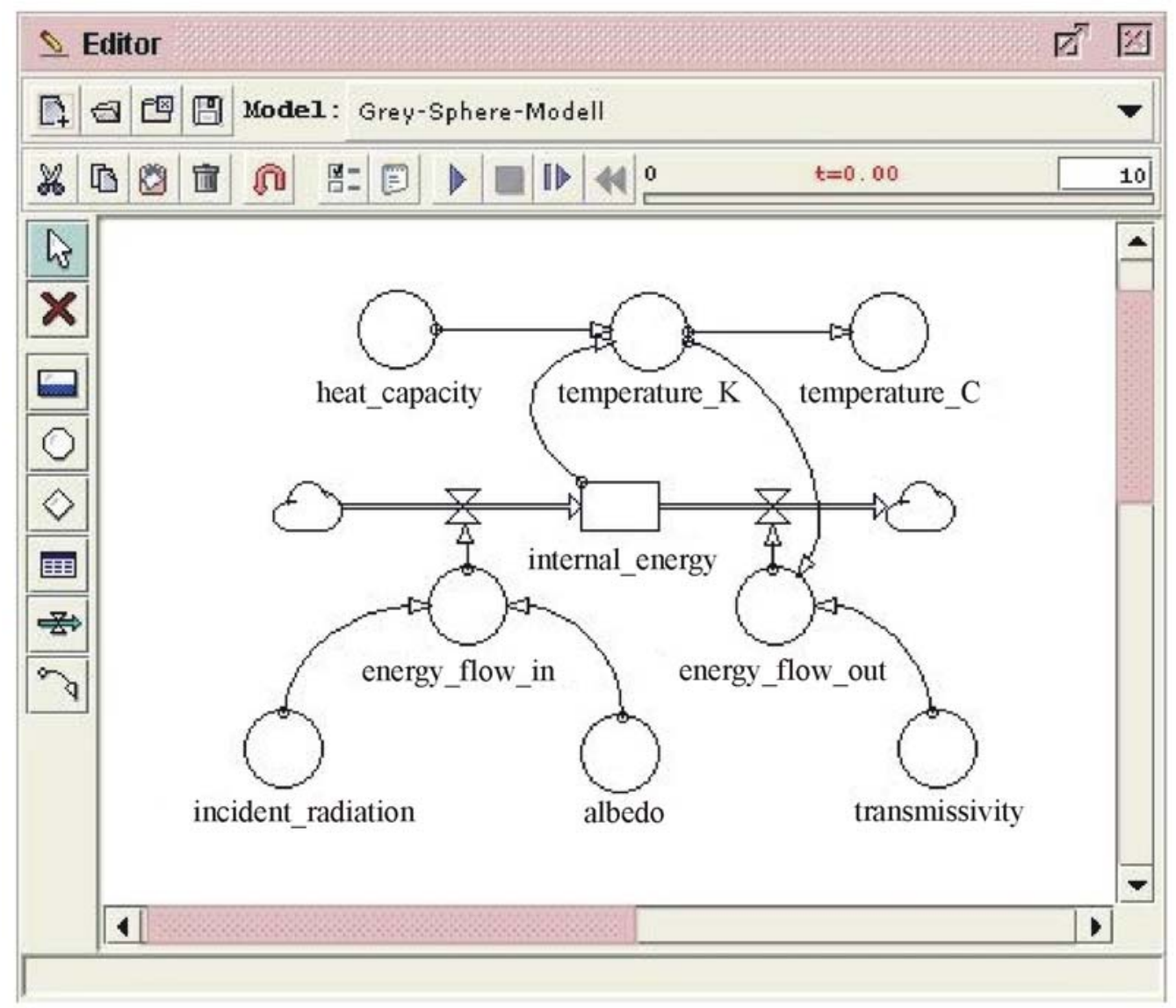




\section{Figure 4}

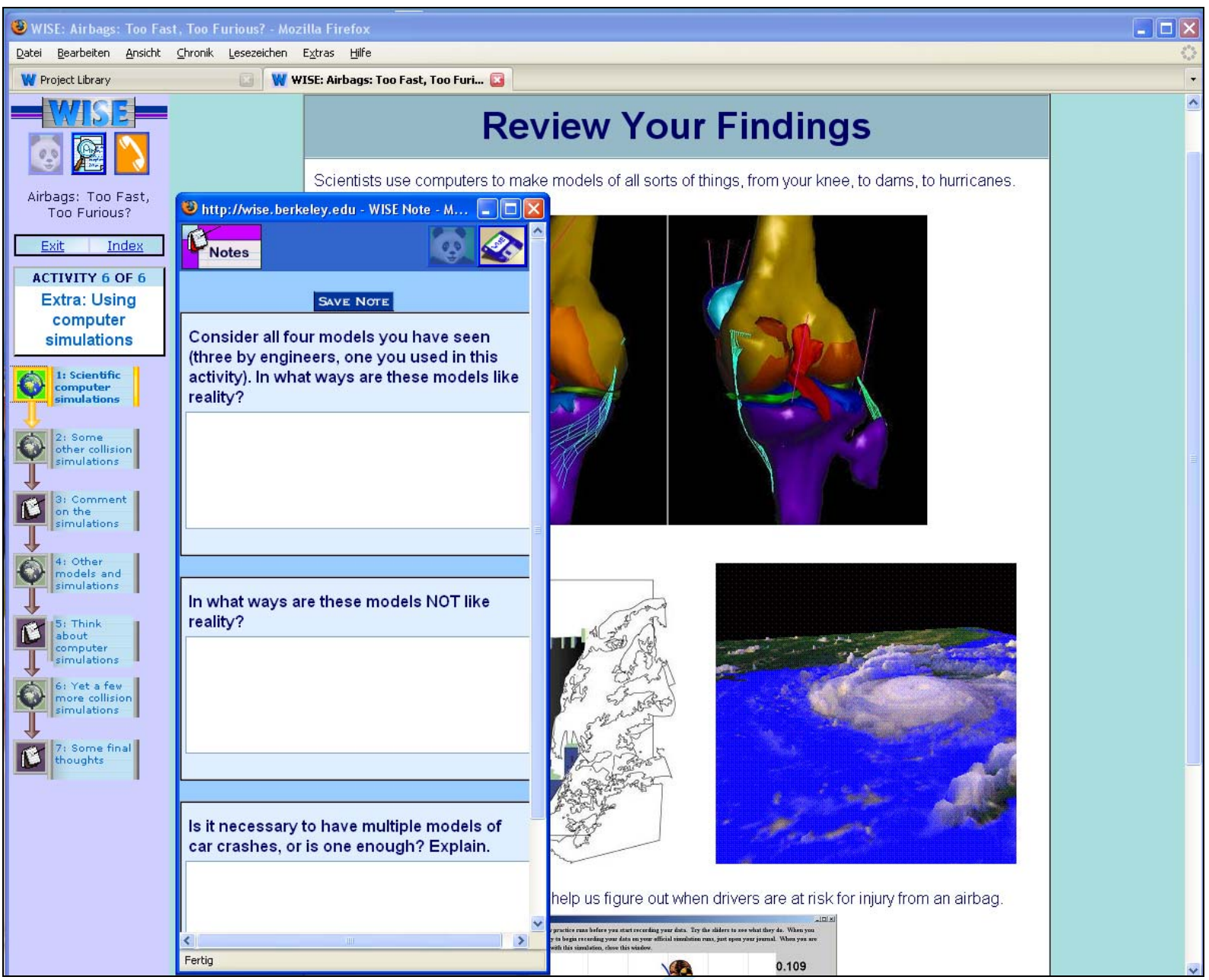


Figure 5
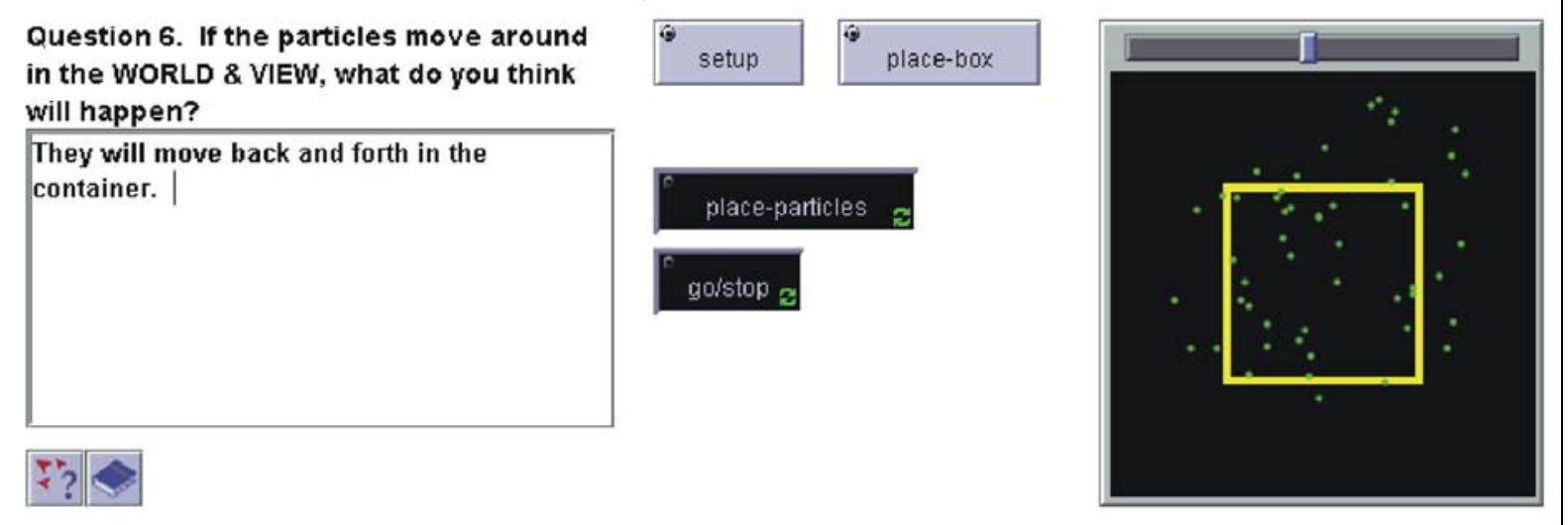

19 


\section{Captions for the Figures for article 1}

Figure 1: The Co-Lab environment showing the control panel (tool menu top left, navigator left centre, team locator bottom left), chat tool (bottom centre), object repository (bottom right) and several tools in the work area (process coordinator top left, a simulation top right, a graph tool bottom left, help manual bottom right).

Figure 2: In the NetCoIL project first syntheses of tools were developed: The Co-Lab simulation 'water tank' (details in the text) was integrated in the Cool Modes environment that provides its table and its graph tool for this investigation. Further, students' analysis is supported by Cool Modes' annotation functionality.

Figure 3: Graphical model editor used to build a simple model of the greenhouse effect (this example was developed in the Co-Lab project).

Figure 4: Evaluative activities in the WISE project on airbags. Activity 6 (see the navigation panel in the left) presents different models of car crashes and from other scientific domains (e.g. models of a knee and of a hurricane) and prompts students to reflect on general aspects of models using the notebook (additional window centre left).

Figure 5: Predictive task in Pedagogica's unit on 'Gas laws'. Students are asked to build a simple model of a bike tyre, consisting of a container and some moving particles, and to predict how the particles will move (left). Then they can test their prediction by running their model (right, NetLogo plug-in) and might be surprised by particles evading from the container. 